\title{
Control of Antigen Receptor Diversity through Spatial Regulation of V(D)J Recombination
}

\author{
Anja Ebert, ${ }^{1}$ Jasna Medvedovic, ${ }^{1,2}$ Hiromi Tagoh,${ }^{1}$ Tanja A. Schwickert, ${ }^{1}$ \\ And Meinrad Busslinger ${ }^{1,3}$ \\ ${ }^{1}$ Research Institute of Molecular Pathology, Vienna Biocenter, A-1030 Vienna, Austria \\ ${ }^{3}$ Correspondence: busslinger@imp.ac.at
}

\begin{abstract}
Lymphocytes recognize a vast variety of pathogens by expressing a diverse repertoire of antigen receptor genes that are assembled by $\mathrm{V}(\mathrm{D}) \mathrm{J}$ recombination in immature B cells $(I g h, I g k)$ and $\mathrm{T}$ cells $(T c r b, T c r a / d)$. V(D)J recombination takes place in the $3^{\prime}$ proximal domain containing the $\mathrm{D}$, J, and C gene segments, whereas 31 (Tcrb) to $200(\operatorname{Igh}) \mathrm{V}$ genes are spread over a large region of $0.67(T c r b)$ to $3(I g k) \mathrm{Mb}$ pairs. All antigen receptor loci undergo reversible contraction at the developmental stage, where they engage in $\mathrm{V}-(\mathrm{D}) \mathrm{J}$ recombination. This long-range looping promotes the participation of all $\mathrm{V}$ genes in $\mathrm{V}-$ (D) J recombination by juxtaposing distant $\mathrm{V}$ genes next to (D) J segments in the proximal recombination center. The B-cellspecific Pax5, ubiquitous YY1, and architectural CTCF/cohesin proteins promote Igh locus contraction in pro-B cells by binding to multiple sites in the $\mathrm{V}_{\mathrm{H}}$ gene cluster. These regulators also control the pro-B-cell-specific activity of the distally located PAIR elements, which are likely involved in the regulation of $\mathrm{V}_{\mathrm{H}}-\mathrm{DJ}_{\mathrm{H}}$ recombination by mediating locus contraction. Notably, the large $\mathrm{V}_{\mathrm{H}}$ gene cluster of the Igh locus undergoes flexible long-range looping that ensures similar participation of all $\mathrm{V}_{\mathrm{H}}$ genes in $\mathrm{V}_{\mathrm{H}}-\mathrm{DJ}_{\mathrm{H}}$ recombination to generate a diverse antibody repertoire.
\end{abstract}

The immune system has a shear unlimited capacity to respond to foreign antigens. Lymphocytes contribute to the enormous adaptive potential of the immune system by expressing a diverse repertoire of antigen receptors that recognize and match the vast diversity of foreign pathogens. The broad antigen receptor repertoire is generated by $\mathrm{V}(\mathrm{D}) \mathrm{J}$ recombination, which assembles the variable regions of immunoglobulin (Ig) and T-cell receptor (Tcr) genes from discontinuous variable (V), diversity (D), and joining $(\mathrm{J})$ gene segments during B- and T-cell development (Fig. 1) (Perlot and Alt 2008; Bossen et al. 2012). $\mathrm{V}(\mathrm{D}) \mathrm{J}$ recombination is tightly regulated in both lymphocyte lineages. During B-lymphopoiesis, the immunoglobulin heavy-chain $(I g h)$ locus rearranges in pro-B cells before recombination of the light-chain genes $I g k$ and $I g l$ in small pre-B cells. Moreover, $\mathrm{D}_{\mathrm{H}}-\mathrm{J}_{\mathrm{H}}$ rearrangements precede $\mathrm{V}_{\mathrm{H}}-\mathrm{DJ}_{\mathrm{H}}$ recombination at the Igh locus, whereas the $I g k$ locus generally rearranges before the $I g l$ locus in pre-B cells (Perlot and Alt 2008). Tcr recombination also occurs at two distinct stages in $\alpha \beta$ T-cell development. The Tcrb locus undergoes $\mathrm{D}_{\beta}-\mathrm{J}_{\beta}$ rearrangements before $\mathrm{V}_{\beta}-\mathrm{DJ}_{\beta}$ recombination in $\mathrm{CD} 4^{-} \mathrm{CD} 8^{-}$double-negative (DN) cells of the thymus, whereas $\mathrm{V}_{\alpha}-\mathrm{J}_{\alpha}$ rearrangements at the $T$ cra locus take place in $\mathrm{CD} 4^{+} \mathrm{CD} 8^{+}$double-positive (DP) thymocytes (Bassing et al. 2002).

The V(D)J recombinase consists of lymphoid RAG1 and RAG2 proteins that initiate site-specific recombination by binding to and introducing double-strand breaks at recombination signal sequences (RSSs) flanking all $I g$ and $T c r$ gene segments. Ubiquitous repair factors of the nonhomologous end joining (NHEJ) machinery subsequently complete the recombination reaction by process- ing and religating the DNA ends (Bassing et al. 2002). The RAG proteins are expressed in all lymphoid progenitors (Igarashi et al. 2002) and immature B and T cells (Jankovic et al. 2004). Hence, the temporal and lineagespecific control of V(D)J recombination is largely determined by the restricted access of the RAG1/2 complex to a subset of RSSs of Ig or Tcr gene segments at the different developmental stages (Perlot and Alt 2008; Bossen et al. 2012). The chromatin accessibility of $I g$ and $\mathrm{Tcr}$ gene segments is controlled at multiple levels including subnuclear relocation (Kosak et al. 2002), DNA demethylation (Mostoslavsky et al. 1998), chromatin remodeling (Kwon et al. 2000), histone modification (Bossen et al. 2012), intergenic antisense RNA expression (Bolland et al. 2004; Ebert et al. 2011), and germline transcription (Yancopoulos and Alt 1985).

Antigen receptor loci consist of a large $\mathrm{V}$ gene cluster ranging from 31 (Tcrb) to $200(I g h) \mathrm{V}$ genes and a $3^{\prime}$ proximal domain containing the $\mathrm{D}, \mathrm{J}$, and constant $(\mathrm{C})$ gene segments together with a potent enhancer (Fig. 1). These two regions are subject to distinct control, because chromatin changes, germline transcription, and $\mathrm{D}-\mathrm{J}$ recombination in the $3^{\prime}$ proximal domain strictly depend on the local enhancer, whereas chromatin accessibility and germline transcription at the $\mathrm{V}$ genes are regulated independently of this enhancer (Mathieu et al. 2003; Hawwari and Krangel 2005; Perlot et al. 2005; Afshar et al. 2006; Chakraborty et al. 2009). The size of the two domains is yet another distinctive feature. The D and J segments of the $I g h$ and $T c r b$ loci are located within a relatively short $50-\mathrm{kb}$ region that readily facilitates $\mathrm{D}-\mathrm{J}$ recombination. In contrast, the $\mathrm{V}$ genes of all major antigen receptor loci

\footnotetext{
${ }^{2}$ Present address: Lymphoid Tissue Development Unit, Institut Pasteur, 75015 Paris, France

Copyright (C) 2013 Cold Spring Harbor Laboratory Press; all rights reserved; doi: 10.1101/sqb.2013.78.019943

Cold Spring Harbor Symposia on Quantitative Biology, Volume LXXVIII
} 
A $\longrightarrow$ Igh locus $\longrightarrow$

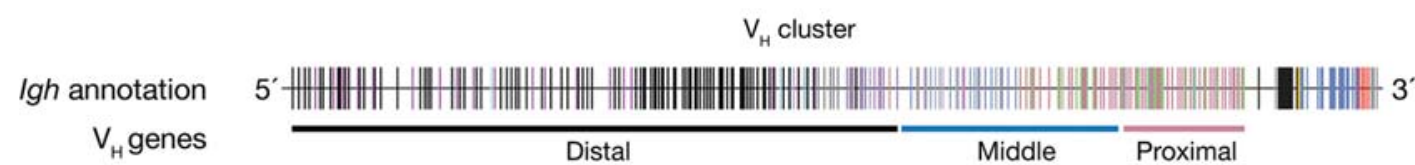

Coordinates
$118,000,000$

$116,000,000$
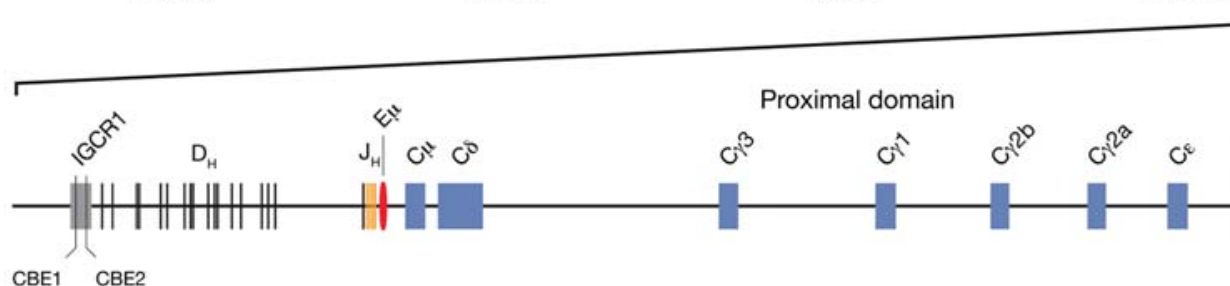

Proximal domain

B
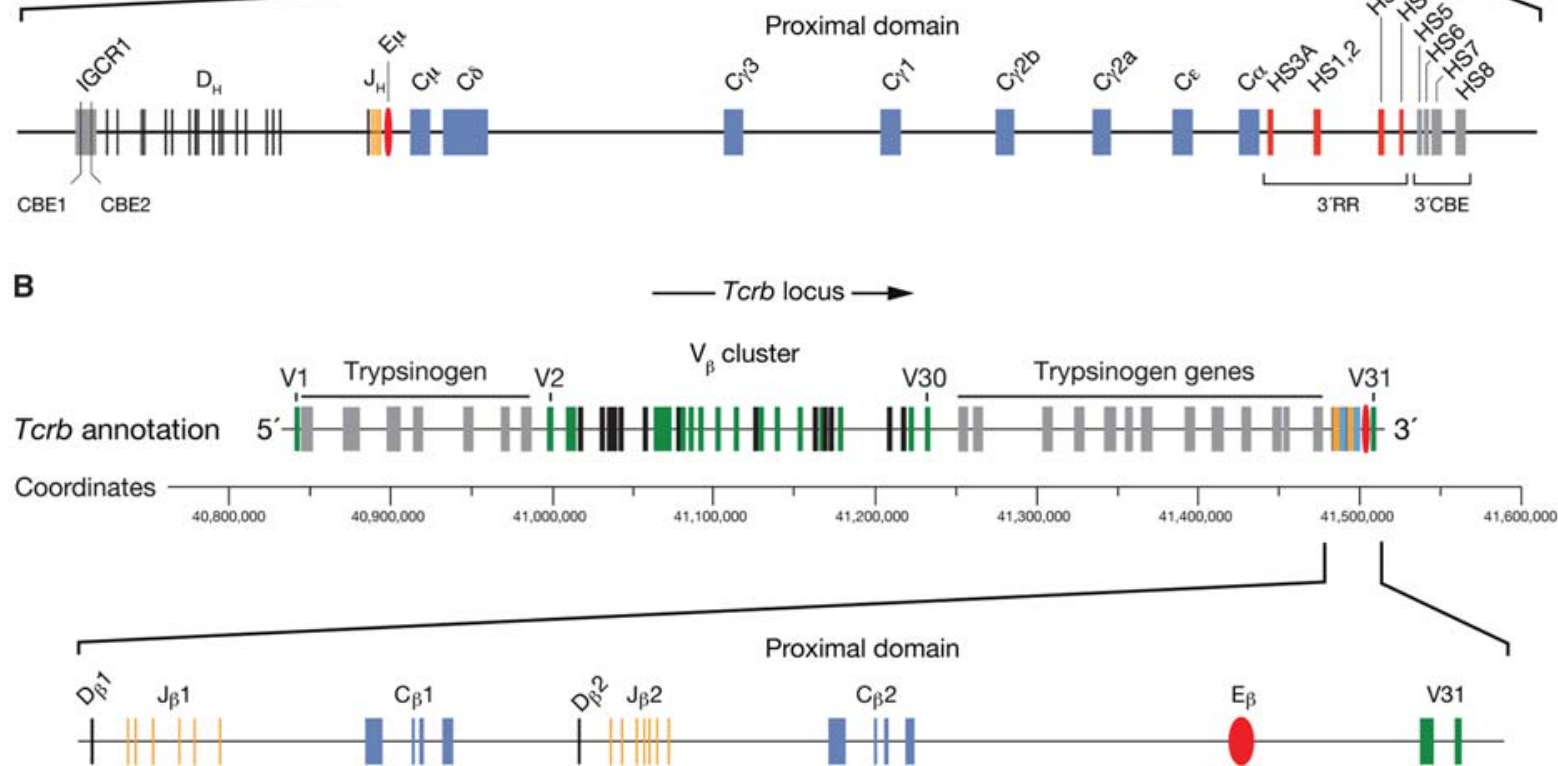

Figure 1. Structure of the $I g h$ and $T c r b$ loci. (A) Schematic diagram of the Igh locus. The distinct $\mathrm{V}_{\mathrm{H}}$ gene families (different colors) in the distal, middle, and proximal $\mathrm{V}_{\mathrm{H}}$ gene regions (Johnston et al. 2006) are shown together with the $\mathrm{D}_{\mathrm{H}}$ (black), $\mathrm{J}_{\mathrm{H}}\left(\right.$ orange), $\mathrm{C}_{\mathrm{H}}($ blue); gene elements; the $\mathrm{E}_{\mu}$ enhancer (red) and $3^{\prime}$ regulatory region ( $3^{\prime} \mathrm{RR}$; red); and the IGCR1 and $3^{\prime} \mathrm{CBE}$ insulators (gray) in the $3^{\prime}$ proximal Igh domain. The mm9 genomic coordinates of mouse chromosome 12 are indicated. HS, DNase I hypersensitive sites; IGCR1, intergenic control region $1 ; 3^{\prime} \mathrm{RR}, 3^{\prime}$ regulatory region; CBE, CTCF-binding element. (B) Schematic diagram of the Tcrb locus indicating the location of functional (green) and nonfunctional (black) $V_{\beta}, D_{\beta}$ (black), $J_{\beta}$ (orange), and $C_{\beta}$ (blue) gene segments together with the $E_{\beta}$ enhancer (red) and 20 trypsinogen genes (grey). The mm9 genomic coordinates of mouse chromosome 6 are indicated.

are spread over a large region of 0.67 (Tcrb), 1.5 (Tcra), $2.4(\operatorname{Igh})$, or $3(\operatorname{Ig} k) \mathrm{Mb}$ pairs, indicating that the $\mathrm{V}-(\mathrm{D}) \mathrm{J}$ recombination step must be spatially restricted (Fig. 1). This is best exemplified by the Tcrb locus, where the presence of 13 inactive trypsinogen genes separates the $\mathrm{V}_{\beta}$ gene cluster from the $3^{\prime}$ proximal domain by a distance of $250 \mathrm{~kb}$ (Fig. 1B). Participation of the $\mathrm{V}$ genes in $\mathrm{V}-(\mathrm{D}) \mathrm{J}$ recombination is therefore only possible if the entire locus undergoes contraction by looping. Here, we discuss the epigenetic and transcriptional mechanisms of this spatial regulation with a particular focus on the $I g h$ locus, which has been best studied in this regard.

\section{REVERSIBLE CONTRACTION AND ALLELIC EXCLUSION OF ANTIGEN RECEPTOR LOCI}

The nuclear periphery and pericentromeric heterochromatin are two repressive compartments in the nucleus that are important for propagating the inactive state of genes (Deniaud and Bickmore 2009). Depending on their activ- ity state, genes are repositioned between these repressive compartments and central nuclear positions that facilitate gene transcription. As shown by three-dimensional DNA fluorescence in situ hybridization (3D DNA-FISH), the $I g h$ and $I g k$ loci are located at the nuclear periphery in all non-B cells including uncommitted lymphoid progenitors (Kosak et al. 2002). The Igh locus is thereby anchored via the distal $\mathrm{V}_{\mathrm{H}}$ genes at the nuclear periphery and is oriented with the $3^{\prime}$ proximal Igh domain toward the center of the nucleus, which facilitates $\mathrm{D}_{\mathrm{H}}-\mathrm{J}_{\mathrm{H}}$ rearrangements in lymphoid progenitors (Fuxa et al. 2004). At the onset of B-cell development, the Igh and $I g k$ loci are relocated from the nuclear periphery to more central positions within the nucleus (Kosak et al. 2002). This subnuclear repositioning likely promotes chromatin opening and germline transcription of the $\mathrm{V}_{\mathrm{H}}$ genes in preparation for $\mathrm{V}_{\mathrm{H}}-\mathrm{DJ}_{\mathrm{H}}$ recombination.

The 3D DNA-FISH experiments also revealed that the two Igh alleles are present in an extended conformation in non-B cells and lymphoid progenitors (Fig. 2) (Kosak et al. 2002; Fuxa et al. 2004). However, in committed pro-B cells, both Igh alleles undergo long-range contrac- 

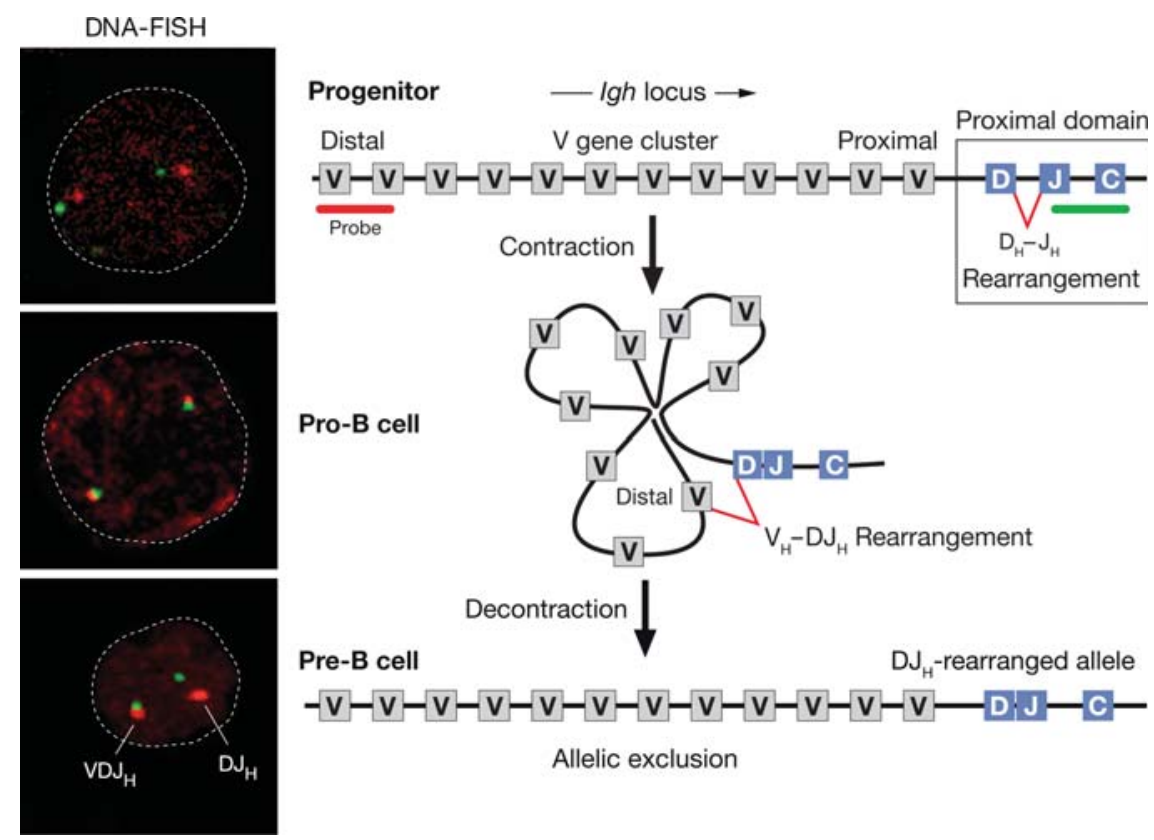

Figure 2. Reversible contraction of the Igh locus. The Igh locus is in an extended configuration in uncommitted progenitors, which allows $\mathrm{D}_{\mathrm{H}}-\mathrm{J}_{\mathrm{H}}$ recombination to take place in the $3^{\prime}$ proximal domain. In committed pro-B cells, all functional $\mathrm{V}_{\mathrm{H}}$ genes participate in $\mathrm{V}_{\mathrm{H}}-\mathrm{DJ}_{\mathrm{H}}$ rearrangements due to contraction of the Igh locus by looping. The $\mathrm{V}_{\mathrm{H}}$ genes of the incompletely rearranged Igh allele are no longer available for $\mathrm{V}_{\mathrm{H}}-\mathrm{DJ}_{\mathrm{H}}$ recombination due to decontraction of the Igh locus in pre-B cells, which results in maintenance of Igh allelic exclusion. DNA-FISH data are shown for Pax $5^{-/-}$progenitors, Rag $2^{-/-}$pro-B cells, and wild-type small pre-B cells (Fuxa et al. 2004; Roldán et al. 2005). The contour of the nucleus is indicated by a dashed line.

tion that juxtaposes distal $\mathrm{V}_{\mathrm{H}}$ genes next to the rearranged proximal $\mathrm{DJ}_{\mathrm{H}}$ domain, thus facilitating $\mathrm{V}_{\mathrm{H}}-\mathrm{DJ}_{\mathrm{H}}$ rearrangements (Fig. 2) (Kosak et al. 2002; Fuxa et al. 2004). The $V_{H}$ gene cluster thereby undergoes looping in such a way that the different $V_{H}$ genes are able to recombine with similar frequency, which is essential for the generation of a diverse immunoglobulin repertoire (Roldán et al. 2005; Sayegh et al. 2005; Jhunjhunwala et al. 2008).

Successful $\mathrm{V}_{\mathrm{H}}-\mathrm{DJ}_{\mathrm{H}}$ recombination of the Igh gene leads to expression of the Ig $\mu$ protein as part of the preB-cell receptor (pre-BCR) complex, which acts as an important checkpoint to promote proliferative cell expansion, maintenance of Igh allelic exclusion, and differentiation to small pre-B cells undergoing Ig light-chain gene recombination (Melchers 2005). Allelic exclusion refers to the inhibition of $\mathrm{V}_{\mathrm{H}}-\mathrm{DJ}_{\mathrm{H}}$ recombination at the second, $\mathrm{DJ}_{\mathrm{H}}$-rearranged allele in small pre-B cells and thus ensures that each B lymphocyte expresses only one monospecific B-cell receptor. Importantly, pre-BCR signaling leads to decontraction of the nonfunctional Igh allele in pre-B cells (Fig. 2), which physically separates the distal $\mathrm{V}_{\mathrm{H}}$ genes from the $3^{\prime}$ proximal Igh domain, thus preventing further recombination of the second, $\mathrm{DJ}_{\mathrm{H}}$-rearranged Igh allele (Roldán et al. 2005). Decontraction is therefore an important mechanism for maintaining Igh allelic exclusion in small pre-B cells. Pre-BCR signaling furthermore leads to the relocation of the nonfunctional $I g h$ allele from euchromatic regions to pericentromeric heterochromatin (Roldán et al. 2005), which is mediated by interchromosomal pairing with a pericentromerically lo- cated Igk allele (Hewitt et al. 2008). Notably, the decontraction of the $I g h$ locus depends on $I g h-I g k$ pairing in a manner that requires a functional $3^{\prime}$ Igк enhancer (Hewitt et al. 2008).

Other antigen receptor loci (Igk, Tcrb, and Tcra/d) also show reversible contraction at the developmental stage, where they undergo V(D)J recombination (Roldán et al. 2005; Skok et al. 2007). Hence, reversible locus contraction by looping is a general mechanism that promotes the spatial communication between $\mathrm{V}$ genes and the $3^{\prime}$ proximal domain and thus allows $\mathrm{V}$ genes to participate in $\mathrm{V}(\mathrm{D}) \mathrm{J}$ recombination. On the other hand, decontraction prevents further recombination at the next developmental stage and thereby contributes to the maintenance of allelic exclusion, which ensures expression of a monospecific antigen receptor in each lymphocyte.

\section{TRANSCRIPTION FACTORS AND REGULATORY ELEMENTS INVOLVED IN LOCUS CONTRACTION}

To date, only a few trans-acting factors have been implicated in the control of locus contraction. 3D DNAFISH analyses identified the B-cell commitment factor Pax 5 as the first transcriptional regulator described to be involved in the pro-B-cell-specific contraction of the Igh locus (Fig. 2) (Fuxa et al. 2004). Pax5 was previously shown to control $\mathrm{V}_{\mathrm{H}}-\mathrm{DJ}_{\mathrm{H}}$ rearrangements, because members of the large $\mathrm{V}_{\mathrm{H}} \mathrm{J} 558$ gene family in the distal Igh region (black lines in Fig. 1A) undergo recombination 
only with a $\sim 100$-fold lower efficiency in Pax5-deficient progenitors compared with wild-type pro-B cells, despite normal $\mathrm{D}_{\mathrm{H}}-\mathrm{J}_{\mathrm{H}}$ recombination in both cell types (Nutt et al. 1997). Subsequent analyses revealed that only the first most proximal of the $200 \mathrm{~V}_{\mathrm{H}}$ genes efficiently undergo $\mathrm{V}_{\mathrm{H}}-\mathrm{DJ}_{\mathrm{H}}$ recombination in the absence of locus contraction, although all $\mathrm{V}_{\mathrm{H}}$ genes are accessible and give rise to germline transcripts in Pax5-deficient progenitors (Hesslein et al. 2003; Roldán et al. 2005). A similar $\mathrm{V}_{\mathrm{H}}-\mathrm{DJ}_{\mathrm{H}}$ recombination phenotype and lack of Igh locus contraction were observed in YY1-deficient pro-B cells, indicating that the ubiquitous transcription factor YY1, like Pax5, contributes to long-range looping at the Igh locus (Liu et al. 2007). Another potential regulator is the CCCTC-binding factor (CTCF), which has been implicated, through its association with the cohesin complex, in long-range chromatin looping at several complex loci (Merkenschlager and Odom 2013). Indeed, shRNA knockdown experiments have suggested a role for the $\mathrm{CTCF} /$ cohesin complex in the regulation of looping at the Igh locus in pro-B cells (Degner et al. 2011). Consistent with this finding, CTCF and cohesin bind together to multiple sites along the $\mathrm{V}_{\mathrm{H}}$ gene cluster of the Igh locus in lymphoid progenitors and committed pro-B cells irrespective of locus contraction (Fig. 3) (Degner et al. 2011; Ebert et al. 2011; Medvedovic et al. 2013). Pax 5 also interacts with numerous sites in the Igh locus (Fig. 3) (Ebert et al. 2011) as well as with the CTCF protein itself (Medvedovic et al. 2013), suggesting that this protein-protein interaction may contribute to longrange looping by promoting contacts between Pax5binding sites and $\mathrm{CTCF} /$ cohesin-binding elements in committed pro-B cells. In contrast, YY1 binds less frequently to the Igh locus, where most of its binding sites are located in the distal $\mathrm{V}_{\mathrm{H}}$ gene region (Fig. 3) (Medvedovic et al. 2013). Interestingly however, YY1 also has the potential to interact with the CTCF protein (Donohoe et al. 2007).
The $\mathrm{V}_{\mathrm{H}}$ gene region likely contains cis-regulatory elements that mediate Igh locus contraction. Until recently, however, $\mathrm{V}_{\mathrm{H}}$ gene promoters were the only known regulatory elements in the entire $\mathrm{V}_{\mathrm{H}}$ gene cluster. By performing a systematic search for intergenic regions with active chromatin, we identified 14 pax5-activated intergenic repeat (PAIR) elements in the distal $\mathrm{V}_{\mathrm{H}}$ gene region of the Igh locus (Fig. 4) (Ebert et al. 2011). These PAIR elements are bound by Pax5, E2A, YY1, CTCF, and cohesin, carry Pax5-dependent active chromatin, and give rise to Pax5-regulated noncoding antisense RNA exclusively in pro-B cells (Fig. 4) (Ebert et al. 2011; Medvedovic et al. 2013). These antisense transcripts also depend on YY1 (Verma-Gaur et al. 2012; Medvedovic et al. 2013), but not on CTCF, because reduced CTCF expression leads to increased antisense transcription (Degner et al. 2011). Importantly, Pax5 no longer binds to PAIR elements in pre-B and B cells, consistent with the loss of antisense RNA expression in these cells. The pro-B-cell-specific and Pax5-dependent activity therefore implicates the PAIR elements in the regulation of distal $\mathrm{V}_{\mathrm{H}}-\mathrm{DJ}_{\mathrm{H}}$ recombination possibly by promoting Igh locus contraction (Ebert et al. 2011). Because PAIR elements 4, 6, and 11 show the highest transcriptional activity within the $\mathrm{V}_{\mathrm{H}}$ gene cluster, they have been postulated to induce long-range looping by relocating the PAIR-containing $\mathrm{V}_{\mathrm{H}}$ gene sequences to transcription factories in the nucleus, where they interact with the $3^{\prime}$ proximal Igh domain containing the highly active $\mathrm{E}_{\mu}$ enhancer (Verma-Gaur et al. 2012). As a consequence, these three PAIR elements should constitute interaction hotspots in the distal $\mathrm{V}_{\mathrm{H}}$ gene region. However, 4C-sequencing (4Cseq) experiments (described below) failed to confirm this hypothesis, because all $\mathrm{V}_{\mathrm{H}}$ gene sequences contact the $3^{\prime}$ proximal Igh domain with similar probability (Fig. 5C) (Medvedovic et al. 2013).

The $\mathrm{E}_{\mu}$ enhancer in the $3^{\prime}$ Igh domain has recently been implicated in the control of Igh locus contraction and thus

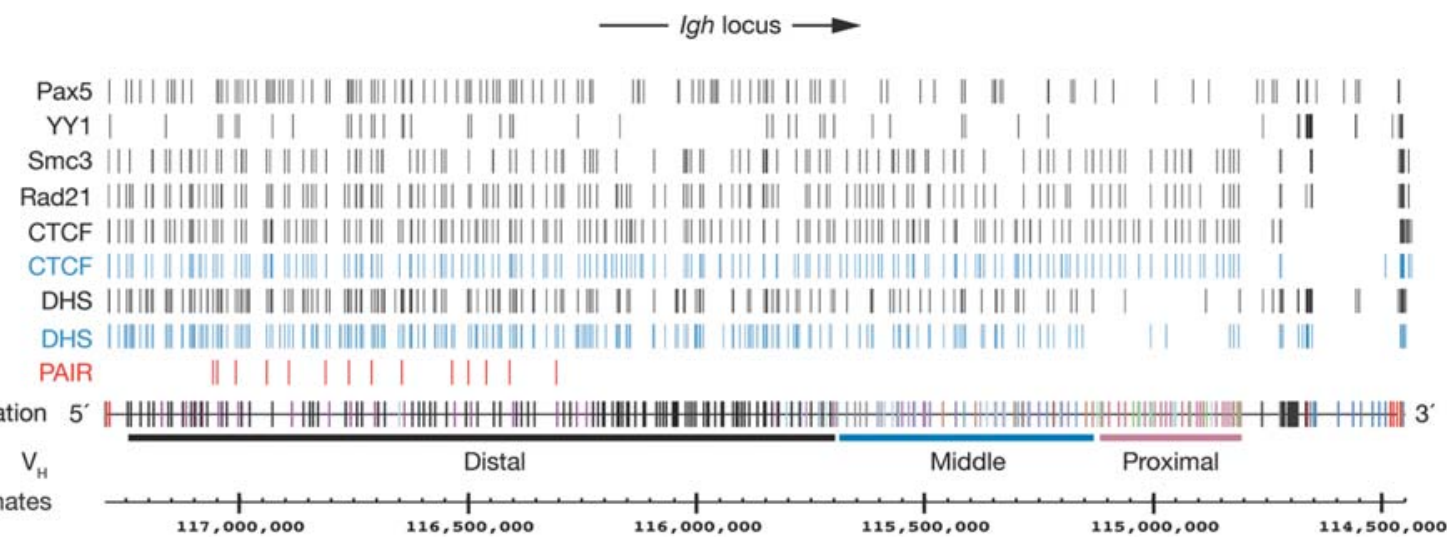

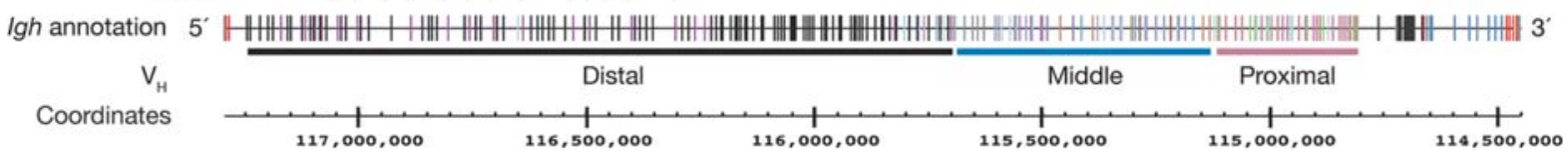

Figure 3. Binding patterns of Pax5, YY1, CTCF, and cohesin at the Igh locus. The indicated binding sites of the transcription factors Pax5, YY1, and CTCF as well as of the cohesin subunits Smc3 and Rad21, were determined by ChIP analysis of Pax $5^{-/-}$progenitors (blue) and Rag2 $2^{-1}$ pro-B cells (black) combined with paired-end sequencing (Ebert et al. 2011; Revilla-i-Domingo et al. 2012, unpubl.). DNase I hypersensitive (DHS) sites, which were also mapped by using paired-end sequencing, are shown for comparison. All ChIP-seq peaks and DHS sites were called with the MACS program using a stringent $p$ value of $<10^{-10}$. The Zfp386 gene located upstream of the Igh locus is indicated by red lines in the Igh annotation. 


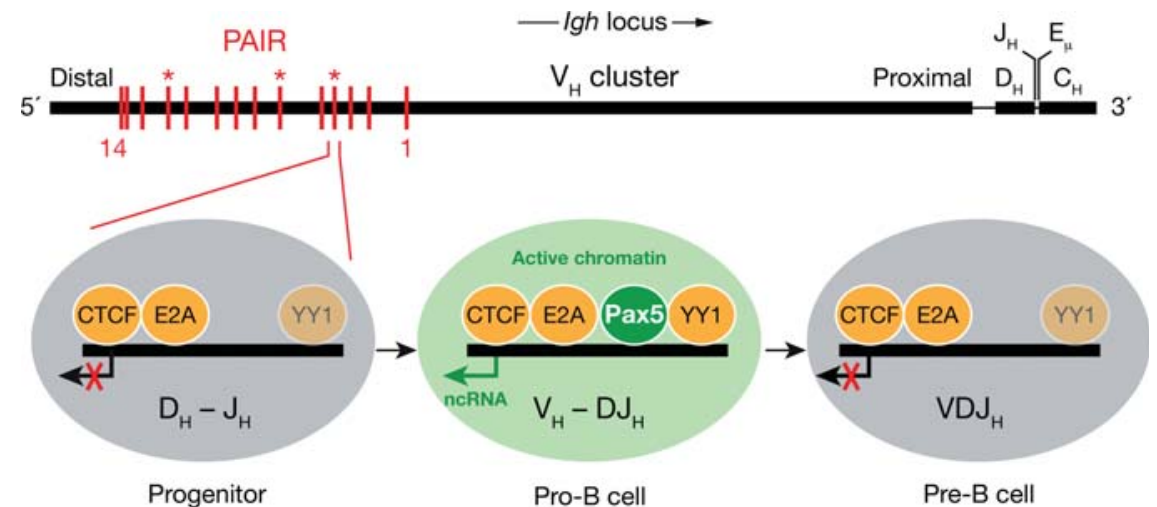

Figure 4. Pro-B-cell-specific activity of the PAIR elements in the distal Igh region. The location of the 14 PAIR elements is indicated together with their chromatin state, transcription factor occupancy, and transcriptional activity in uncommitted progenitors, committed pro-B cells and small pre-B cells (Ebert et al. 2011). Asterisks indicated the three PAIR elements with the highest transcriptional activity (Verma-Gaur et al. 2012). CTCF was shown to interact with cohesin at the PAIR elements (Ebert et al. 2011). The binding of YY1 was so far analyzed only in pro-B cells by ChIP-seq. Binding of YY1 in the progenitors and pre-B cells is currently hypothetical and only inferred due to the ubiquitous expression of this transcription factor.

A Local interaction domains Long-range interactions
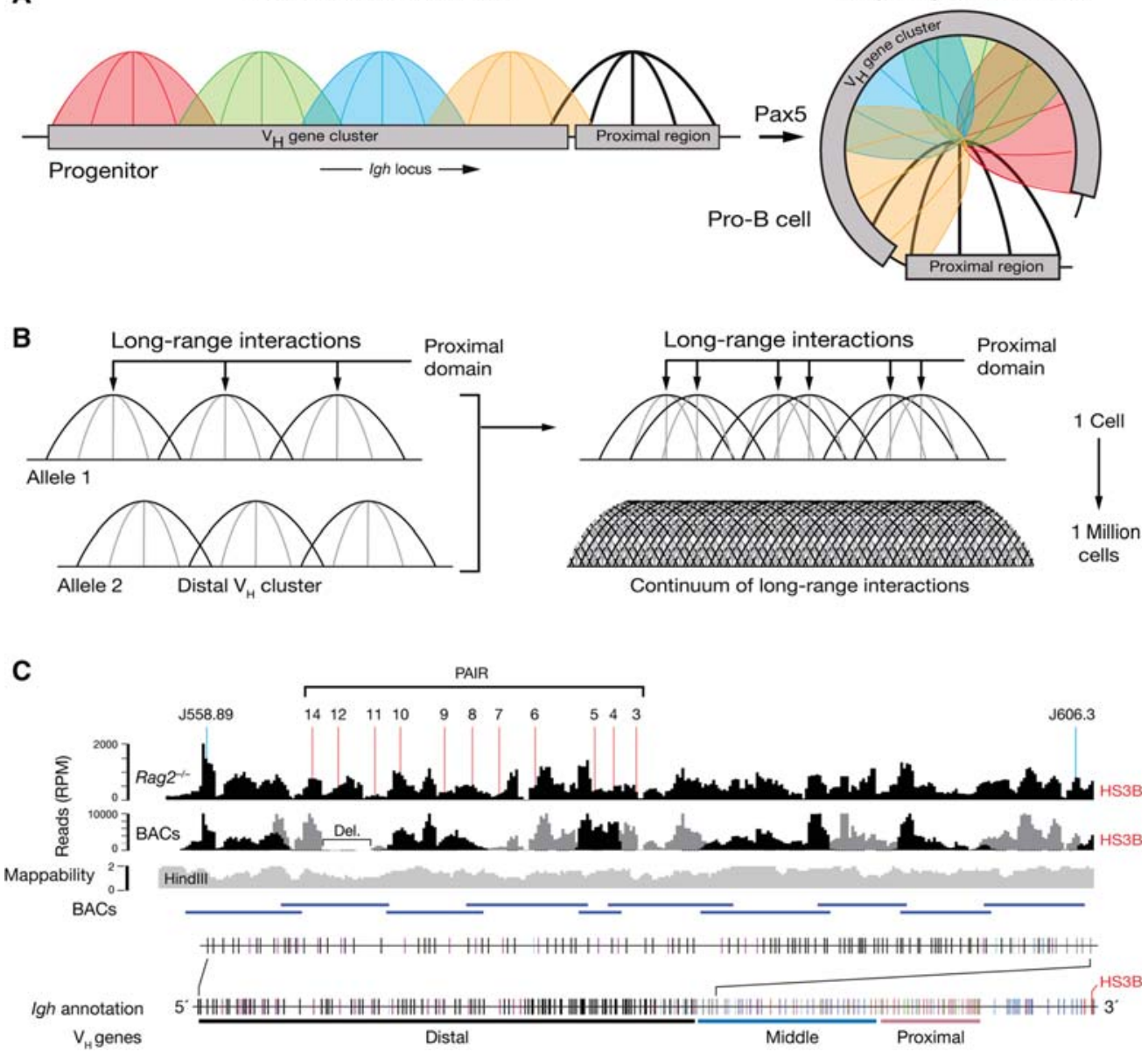

Figure 5. Flexible long-range loops across the $\mathrm{V}_{\mathrm{H}}$ gene cluster. $(A)$ Illustration depicting the Igh locus in its "extended" conformation with overlapping local interaction domains and in its contracted state with long-range interactions connecting the local interaction domains. (B) Simplified diagram indicating how flexible local interactions in the $\mathrm{V}_{\mathrm{H}}$ gene region may result in a continuum of chromatin loops across the $\mathrm{V}_{\mathrm{H}}$ gene cluster in a population of 1 million pro- $\mathrm{B}$ cells that were used for $4 \mathrm{C}$ sequencing. $(C)$ Comparison of $4 \mathrm{C}$-seq patterns obtained with $\mathrm{Rag}^{-/-}$pro-B cells and random bacterial artificial chromosome (BAC) libraries that were analyzed with an HS3B viewpoint in the $3^{\prime}$ proximal Igh domain (Fig. 1A). The 4C-seq data were plotted as reads per million (RPM) mapped sequence reads. The mappability track (gray) indicates to what degree (on a scale from 0 to 2 ) the end sequences of the analyzed HindIII fragments could be unambiguously mapped to genomic Igh sequences. (C, Adapted, with permission, from Medvedovic et al. 2013.) 
$\mathrm{V}_{\mathrm{H}}-\mathrm{DJ}_{\mathrm{H}}$ recombination (Guo et al. 2011a). This conclusion was mainly based on 3D DNA-FISH analyses demonstrating that the $I g h$ locus is present in an extended conformation in $\mathrm{E}_{\mu}^{-/-} \mathrm{Rag}^{-/-}$pro-B cells in contrast

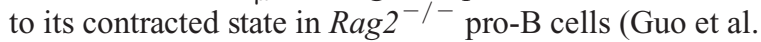
2011a). By performing 3D DNA-FISH and 4C-sequencing experiments with the same pro-B cell types, we could not, however, confirm a role for the $\mathrm{E}_{\mu}$ enhancer in the regulation of $I g h$ locus contraction by these two independent methods (Medvedovic et al. 2013). Previous analyses revealed an essential role of the $\mathrm{E}_{\mu}$ enhancer in controlling the chromatin accessibility and transcriptional activation of the $3^{\prime}$ proximal $\operatorname{Ig} h$ domain, because active histone marks (H3K4me3 and H3K9ac), germline transcripts $\left(\mu^{0}\right.$ and $\left.\mathrm{I}_{\mu}\right)$, and $\mathrm{D}_{\mathrm{H}}-\mathrm{J}_{\mathrm{H}}$ recombination are severely reduced in $\mathrm{E}_{\mu}{ }^{-/-}$pro-B cells (Perlot et al. 2005; Afshar et al. 2006; Chakraborty et al. 2009). Hence, the observed block of $\mathrm{V}_{\mathrm{H}}-\mathrm{DJ}_{\mathrm{H}}$ recombination is likely a secondary consequence of the strongly reduced number of $\mathrm{DJ}_{\mathrm{H}}$-rearranged $I g h$ alleles in $\mathrm{E}_{\mu}{ }^{-\rho-}$ pro-B cells (Perlot et al. 2005; Afshar et al. 2006). Notably, the recombination of proximal and distal $\mathrm{V}_{\mathrm{H}}$ genes is equally affected by deletion of the $E_{\mu}$ enhancer (Perlot et al. 2005), in contrast to the preferential loss of distal $\mathrm{V}_{\mathrm{H}}-\mathrm{DJ}_{\mathrm{H}}$ recombination in the absence of locus contraction (Fuxa et al. 2004). Moreover, germline $V_{H}$ gene transcription is unaffected in $\mathrm{E}_{\mu}^{-/-}$pro-B cells, further indicating that the activity of the $\mathrm{E}_{\mu}$ enhancer is restricted to the $3^{\prime}$ proximal Igh domain (Perlot et al. 2005; Afshar et al. 2006).

\section{CONTROL OF V(D)J RECOMBINATION BY INSULATORS}

CTCF has been implicated not only in chromosome looping but also in chromatin boundary formation, transcriptional insulation, activation, or repression (Phillips and Corces 2009). A large array of regularly spaced CTCF-binding sites characterizes the $\mathrm{V}$ gene clusters of all antigen receptor loci, whereas the $3^{\prime}$ proximal domains contain CTCF-binding sites only at their $5^{\prime}$ and $3^{\prime}$ boundaries (Fig. 3) (Degner et al. 2011; Ebert et al. 2011; Ribeiro de Almeida et al. 2011; Seitan et al. 2011; Shih et al. 2012). The CTCF-binding sites at the $5^{\prime}$ end of the proximal domain act as insulators, as exemplified by the Sis element, which is located between the $V_{K}$ and $J_{K}$ segments and functions as a silencer of $I g k$ recombination by binding of transcription factors CTCF and Ikaros (Liu et al. 2006; Ribeiro de Almeida et al. 2011). Deletion of the Sis element or conditional inactivation of CTCF similarly affect $V_{K}-J_{K}$ rearrangements in pre-B cells by increasing germline transcription and recombination of proximal $V_{K}$ genes at the expense of distal $V_{K}$ gene recombination (Ribeiro de Almeida et al. 2011; Xiang et al. 2011). The loss of CTCF thereby skews the repertoire of $\mathrm{V}_{\mathrm{K}}-\mathrm{J}_{\mathrm{K}}$ rearrangements by strongly increasing the interactions of the $\mathrm{iE}_{\mathrm{K}}$ and $3^{\prime} \mathrm{E}_{\mathrm{K}}$ enhancers with proximal $\mathrm{V}_{\mathrm{K}}$ genes (Ribeiro de Almeida et al. 2011). This evidence suggests that the Sis element functions as an insulator to negatively regulate proximal $V_{\kappa}$ gene recombination by blocking the long-range activity of the $E_{\kappa}$ enhancers (Ribeiro de Almeida et al. 2011). Long-range looping across the $V_{\kappa}$ gene cluster is, however, normal in Sisdeficient pre-B cells, indicating that the Sis element does not contribute to $I g k$ locus contraction (Xiang et al. 2011).

The best-characterized insulator of the Igh locus is the intergenic control region 1 (IGCR1), containing two CTCF-binding elements (CBEs) that are located $2 \mathrm{~kb}$ upstream of the $\mathrm{D}_{\mathrm{H}} \mathrm{FL} 16.1$ gene segment in the intervening $\mathrm{V}_{\mathrm{H}}-\mathrm{D}_{\mathrm{H}}$ region (Fig. 1A) (Guo et al. 2011b). Specific mutation of the CBEs showed that the two CTCF-binding sites function as insulator elements to regulate ordered and lineage-specific V(D)J recombination at the Igh locus (Guo et al. 2011b). In uncommitted lymphoid progenitors, the IGCR1/CBE insulator restricts the potent $\mathrm{E}_{\mu}$ enhancer activity as well as all other looping interactions to the $3^{\prime}$ proximal domain, which generates a local chromatin structure that promotes $\mathrm{D}_{\mathrm{H}}-\mathrm{J}_{\mathrm{H}}$ recombination on both Igh alleles (Guo et al. 2011b). During normal development, the IGCR1/CBE insulator is only neutralized in committed pro-B cells, possibly by Pax5-dependent contraction of the Igh locus, which facilitates $\mathrm{V}_{\mathrm{H}^{-}}$ $\mathrm{DJ}_{\mathrm{H}}$ recombination. In IGCR1/CBE mutant mice, the activity of the $\mathrm{E} \mu$ enhancer is, however, no longer restrained and thus induces active chromatin and germline transcription at the first few proximal $V_{H}$ genes that undergo premature $\mathrm{V}_{\mathrm{H}}-\mathrm{DJ}_{\mathrm{H}}$ and even $\mathrm{V}_{\mathrm{H}}-\mathrm{D}_{\mathrm{H}}$ recombination in lymphoid progenitors and developing thymocytes (Guo et al. 2011b). As a consequence of the precocious proximal $\mathrm{V}_{\mathrm{H}}$ gene activity in lymphoid progenitors, fewer $\mathrm{DJ}_{\mathrm{H}}$-rearranged Igh alleles are available for $\mathrm{V}_{\mathrm{H}}-\mathrm{DJ}_{\mathrm{H}}$ recombination in committed pro-B cells, which leads to a strong increase of proximal $\mathrm{V}_{\mathrm{H}}$ gene rearrangements and a corresponding skewing of the immunoglobulin repertoire. Hence, the CTCF-regulated IGCR1 activity and Pax5-mediated locus contraction fulfill opposing roles by preventing or promoting the participation of $\mathrm{V}_{\mathrm{H}}$ genes in $\mathrm{V}(\mathrm{D}) \mathrm{J}$ recombination in lymphoid progenitors or committed pro-B cells, respectively.

\section{THE "EXTENDED" IGH LOCUS CONSISTS OF OVERLAPPING LOCAL INTERACTION DOMAINS IN UNCOMMITTED PROGENITORS}

The spatial conformation of antigen receptor loci has so far been studied in single cells at low resolution by DNA-FISH analysis. In contrast, high-resolution analysis of chromatin looping at the cell population is provided by $4 \mathrm{C}$-seq, which is based on the chromosome conformation capture-on-chip technique adapted for deep sequencing (van de Werken et al. 2012). Our recent 4C-seq analyses revealed that the Igh locus in its "extended" configuration consists of distinct local interaction domains ranging from $0.5 \mathrm{Mb}\left(3^{\prime}\right.$ proximal region) to $1.3 \mathrm{Mb}\left(5^{\prime}\right.$ PAIR region) in thymocytes and uncommitted $\mathrm{Pax}^{-/-}$progenitors (Fig. 5A) (Medvedovic et al. 2013). These local interaction domains may consist of rosettes of chromatin loops that have been predicted to be the organizational 
units of the Igh locus in uncommitted pre-/pro-B cells based on computer simulation of distance measurements among 12 distinct DNA-FISH probes (Jhunjhunwala et al. 2008). Global Hi-C analyses of embryonic stem, pre-/pro-B, and pro-B cells revealed that the entire mouse genome is organized into local chromatin interaction regions referred to as topological domains that range from 0.5 to $3 \mathrm{Mb}$ in size (Dixon et al. 2012; Lin et al. 2012; Nora et al. 2012). The local interaction domains of the $I g h$ locus also fit this size range, show a similar 4C-seq pattern in lymphoid progenitors and thymocytes and may thus correspond to topological domains, which are largely invariant between different cell types (Dixon et al. 2012; Lin et al. 2012). Hence, the local interaction domains likely constitute the default folding state of the "extended" Igh locus in non-B cells.

Previous 3C analyses of the $3^{\prime}$ proximal Igh domain identified loops between the regulatory IGCR1, $\mathrm{E}_{\mu}$, $3^{\prime} \mathrm{RR}$, and $3^{\prime} \mathrm{CBE}$ regions (see Fig. 1A) (Degner et al. 2011; Guo et al. 2011a,b). In addition to the known chromatin loops, our 4C-seq analysis detected novel interactions of these regulatory elements with the $\mathrm{C} \gamma 1-\mathrm{C} \gamma 2 \mathrm{~b}$ intervening region as well as with the first proximal $\mathrm{V}_{\mathrm{H}}$ genes in thymocytes, lymphoid progenitors, and committed pro-B cells (Medvedovic et al. 2013). The incorporation of these $\mathrm{V}_{\mathrm{H}}$ genes into the local 3D architecture of the 3 ' proximal Igh domain explains why only the first proximal $\mathrm{V}_{\mathrm{H}}$ genes undergo $\mathrm{V}_{\mathrm{H}}-\mathrm{DJ}_{\mathrm{H}}$ recombination in the absence of locus contraction in Pax5-deficient progenitors (Hesslein et al. 2003; Roldán et al. 2005). The same $\mathrm{V}_{\mathrm{H}}$ genes also interact with the $3^{\prime}$ proximal Igh domain in thymocytes (Medvedovic et al. 2013), although they never undergo $\mathrm{V}_{\mathrm{H}}-\mathrm{DJ}_{\mathrm{H}}$ recombination during normal T-cell development, unless the IGCR1 insulator is inactivated by mutation of its two CBEs (Guo et al. 2011b). Hence, a functional IGCR1 element prevents $\mathrm{V}_{\mathrm{H}}-\mathrm{DJ}_{\mathrm{H}}$ recombination even if $\mathrm{V}_{\mathrm{H}}$ genes participate in looping with the $3^{\prime}$ proximal Igh domain in thymocytes.

\section{FLEXIBLE LONG-RANGE INTERACTIONS ACROSS THE $V_{H}$ GENE CLUSTER MEDIATE LOCUS CONTRACTION IN PRO-B CELLS}

In committed pro-B cells, all local interaction domains engage in long-range looping across the Igh locus, which depends on Pax5, YY1, and CTCF as shown by 4C-seq analysis (Fig. 5A) (Medvedovic et al. 2013). 5' and $3^{\prime}$ boundaries near the first $5^{\prime} \mathrm{V}_{\mathrm{H}} \mathrm{J} 558$ gene and at the $3^{\prime} \mathrm{CBE}$ region (Fig. 1A) restrict these long-range interactions to the Igh locus, which constitutes one large chromosome-folding unit in pro-B cells. Notably, locus contraction did not affect the interactions within the local domains, but instead provided an additional layer of longrange looping among these domains. As shown with 4Cseq, the $3^{\prime}$ proximal region, which contains the recombination center of the Igh locus (Ji et al. 2010), assumes a rigid chromatin structure, where most long-range loops from the $\mathrm{V}_{\mathrm{H}}$ gene region contact the IGCR1 and $3^{\prime} \mathrm{CBE}$ regions containing the only $\mathrm{CTCF} /$ cohesin-binding sites in the $3^{\prime}$ proximal region (Fig. 3) (Medvedovic et al. 2013). Unexpectedly, however, the long-range loops appear to initiate at a multitude of sites in the $\mathrm{V}_{\mathrm{H}}$ gene region, which results in a continuum of flexible longrange interactions across the entire $\mathrm{V}_{\mathrm{H}}$ gene cluster in a population of pro-B cells (Fig. 5B) (Medvedovic et al. 2013). Given the critical role of the CTCF/cohesin complex in chromatin looping (Merkenschlager and Odom 2013), it is conceivable that the regularly spaced $\mathrm{CTCF} /$ cohesin-binding sites (Fig. 3) may anchor the long-range loops in the $\mathrm{V}_{\mathrm{H}}$ gene region. Importantly, the $4 \mathrm{C}$-seq patterns of the distal $\mathrm{V}_{\mathrm{H}}$ gene region were similar for the local interaction domains in Pax5-deficient progenitors (before locus contraction) and the corresponding long-range loops in committed pro-B cells (undergoing locus contraction) (Medvedovic et al. 2013). This evidence strongly suggests that the observed flexibility may be a characteristic feature of the local interaction domains in the $\mathrm{V}_{\mathrm{H}}$ gene region, as depicted in Figure 5B. The $4 \mathrm{C}$-seq data shown in Figure $5 \mathrm{C}$ provide the strongest argument for flexible long-range looping, because the chromatin of $\mathrm{Rag}^{-/}$pro-B cells and randomly ligated DNA fragments of overlapping Igh bacterial artificial chromosomes (BACs) gave rise to similar $4 \mathrm{C}$-seq patterns with the HS3B viewpoint in the $3^{\prime}$ proximal region (Medvedovic et al. 2013). We therefore hypothesize that the flexible long-range interactions provide, at the pro-B-cell population level, a similar probability for each $\mathrm{V}_{\mathrm{H}}$ gene to be juxtaposed next to the $\mathrm{DJ}_{\mathrm{H}^{-}}$ rearranged gene segment in the $3^{\prime}$ proximal Igh domain to undergo $\mathrm{V}_{\mathrm{H}}-\mathrm{DJ}_{\mathrm{H}}$ recombination. By promoting equal participation of all $\mathrm{V}_{\mathrm{H}}$ genes in $\mathrm{V}_{\mathrm{H}}-\mathrm{DJ}_{\mathrm{H}}$ recombination, flexible long-range loops likely contribute to the generation of a diverse antibody repertoire that is essential for an effective immune response to foreign pathogens. It is, however, important to note that individual $\mathrm{V}_{\mathrm{H}}$ genes rearrange at different frequencies in pro-B cells (Choi et al. 2013). Hence, in addition to the essential requirement for locus contraction, the recombination rate of a given $\mathrm{V}_{\mathrm{H}}$ gene is determined also by other parameters such as the functionality of the $\mathrm{V}_{\mathrm{H}}$ RSS elements (Choi et al. 2013).

Our 4C-seq and 3D DNA-FISH analyses furthermore revealed that individual mutation of the IGCR1 element, $E_{\mu}$ enhancer, or $3^{\prime}$ regulatory region $\left(3^{\prime} R R\right)$ in the $3^{\prime}$ proximal Igh domain does not affect locus contraction. These data further support the notion that the $\mathrm{V}_{\mathrm{H}}$ gene region and $3^{\prime}$ proximal domain of the Igh locus fulfill distinct roles in $\mathrm{V}(\mathrm{D}) \mathrm{J}$ recombination. The primary function of the $\mathrm{V}_{\mathrm{H}}$ gene cluster seems to be the formation of flexible longrange loops to present the different $\mathrm{V}_{\mathrm{H}}$ genes to the $3^{\prime}$ proximal domain, which functions as the business end of the Igh locus where V(D)J recombination takes place.

\section{ACTIVE CHROMATIN AND THE CONTROL OF SEQUENTIAL REARRANGEMENTS AT THE RECOMBINATION CENTER}

The accessibility hypothesis, published already 28 years ago, postulates that the initial step in the control 
of $\mathrm{V}(\mathrm{D}) \mathrm{J}$ recombination must be chromatin changes that render the different gene segments of the antigen receptor loci accessible to the $\mathrm{V}(\mathrm{D}) \mathrm{J}$ recombination machinery (Yancopoulos and Alt 1985). In the meantime, it is well established that the $3^{\prime}$ proximal domain of antigen receptor loci is activated at the chromatin level by enhancermediated recruitment of chromatin-remodeling and histone-modifying enzymes (Mathieu et al. 2000; McMurry and Krangel 2000; Chakraborty et al. 2009). As a consequence, the intronic $\mathrm{E}_{\mu}$ enhancer and adjacent $\mathrm{J}_{\mathrm{H}}$ segments are characterized by an abundance of the three active histone marks $\mathrm{H} 3 \mathrm{~K} 4 \mathrm{me} 2, \mathrm{H} 3 \mathrm{~K} 4 \mathrm{me} 3$, and H3K9ac in pro-B cells (Fig. 6A) (Chakraborty et al. 2009; Malin et al. 2010), which strongly express the germline transcripts $\mu^{0}$ and $I_{\mu}$ as a proxy for chromatin accessibility (Verma-Gaur et al. 2012). However, it is less clear what defines the accessible state of the $\mathrm{V}$ genes before $\mathrm{V}-(\mathrm{D}) \mathrm{J}$ recombination. For instance, the $\mathrm{V}_{\mathrm{H}}$ genes of the Igh locus are characterized by nucleosomal reorganization and increased DNase I hypersensitivity in Rag $2^{-/-}$pro-B cells (Maes et al. 2001), which may explain the observed low level of germline $\mathrm{V}_{\mathrm{H}}$ gene transcription (Yancopoulos and Alt 1985; Verma-Gaur et al. 2012). Initial chromatin precipitation experiments implicated histone acetylation as an important mechanism for activating the chromatin at $\mathrm{V}$ genes (Chowdhury and Sen 2001; Tripathi et al. 2002). However, systematic chromatin profiling of the Igh locus by ChIP-chip and ChIP-seq analyses subsequently revealed that the active histone marks $\mathrm{H} 3 \mathrm{~K} 4 \mathrm{me} 2, \mathrm{H} 4 \mathrm{~K} 4 \mathrm{me} 3$, and $\mathrm{H} 3 \mathrm{~K} 9 \mathrm{ac}$ are either absent or only present at low levels at most $\mathrm{V}_{\mathrm{H}}$ genes except for members of the distal $\mathrm{V}_{\mathrm{H}} 3609$ gene family that carry relatively high detectable levels of H3K4me2 and H3K9ac (Fig. 6A) (Malin et al. 2010; Choi et al. 2013). Notably, the entire $\mathrm{V}_{\mathrm{H}}$ gene cluster contains only three $\mathrm{H} 4 \mathrm{~K} 4 \mathrm{me} 3$ peaks at the most highly active PAIR4 and PAIR6 elements as well as at another intergenic region located in the middle $\mathrm{V}_{\mathrm{H}}$ gene cluster (Fig. 6A) (Malin et al. 2010; Choi et al. 2013). Hence, most $\mathrm{V}_{\mathrm{H}}$ genes do not show an active histone modification signature $\left(\mathrm{H} 3 \mathrm{~K} 4 \mathrm{me} 2^{+} \mathrm{H} 4 \mathrm{~K} 4 \mathrm{me} 3^{+} \mathrm{H} 3 \mathrm{~K} 9 \mathrm{ac}^{+}\right)$characteristic of expressed genes, and yet their chromatin must be accessible enough to facilitate $\mathrm{V}_{\mathrm{H}}-\mathrm{DJ}_{\mathrm{H}}$ recombination in pro-B cells.

A possible explanation for this asymmetric distribution of active chromatin at the Igh locus and other antigen receptor loci may be provided by the fact that the RAG2 protein contains at its carboxyl terminus a plant homeodomain (PHD) finger that specifically binds the active histone mark H3K4me3 (Matthews et al. 2007) at active promoters throughout the genome (Ji et al. 2010). Importantly, RAG2 also binds to the H3K4me3 island at the J gene segments of the different antigen receptor loci (Igh, $I g k, T c r b$, and Tcra $/ d$ ), once they become accessible during lymphocyte development (Fig. 6B) (Ji et al. 2010). The RAG1 protein interacts in a more restrictive manner only with the RSS elements of the accessible J gene segments and thus further contributes to the focal and stable recruitment of the RAG1/2 complex to the active chromatin region in the $3^{\prime}$ proximal region of antigen receptor loci referred to as the recombination center (Fig. 6B) (Ji et al. 2010). As exemplified for the Igh locus, the RAG1/ 2 complex, once tethered to the $\mathrm{J}_{\mathrm{H}}$ segments at the recombination center, can capture a partner RSS element of a $\mathrm{D}_{\mathrm{H}}$ segment to undergo synapse formation (Fig. 6B). After $\mathrm{D}_{\mathrm{H}}-\mathrm{J}_{\mathrm{H}}$ recombination in lymphoid progenitors, the rearranged $\mathrm{D}_{\mathrm{H}}$ element is also incorporated into the active chromatin domain and bound by the RAG1/2 complex that can now capture an RSS element of one of the many $\mathrm{V}_{\mathrm{H}}$ gene segments to undergo $\mathrm{V}_{\mathrm{H}}-\mathrm{DJ}_{\mathrm{H}}$ rearrangement in pro-B cells. The H3K4me3-mediated focal targeting of the RAG1/2 endonuclease to the recombination center is a likely reason why active chromatin is asymmetrically distributed at the proximal $\mathrm{J}_{\mathrm{H}}$ region and not throughout the $\mathrm{D}_{\mathrm{H}}$ and $\mathrm{V}_{\mathrm{H}}$ gene clusters in pro-B cells. Importantly, the localized activity of the RAG1/2 complex at the proximal chromatin hub strictly depends on locus contraction to present the $\mathrm{V}$ genes to the recombination center for subsequent generation of a functional V(D)J-rearranged antigen receptor gene.

\section{CONCLUDING REMARKS}

Locus contraction is essential for the generation of a diverse antigen receptor repertoire, because it promotes $\mathrm{V}-(\mathrm{D}) \mathrm{J}$ recombination at all major antigen receptor loci. Despite its importance for humoral immunity, we still know little about the molecular mechanisms underlying locus contraction. Although Pax5, YY1, and the CTCF/ cohesin complex have been identified as important regulators of locus contraction, it is currently unclear how they contribute to this process. For instance, the CTCF/cohesin complex shows a similar binding pattern along the Igh locus both in the presence or absence of locus contraction. The question therefore arises as to what signals or factors allow this complex as well as the ubiquitous YY1 protein to participate in long-range interactions only in pro-B cells. Although the B-cell-specific regulator Pax5 is a prime candidate for this job, the molecular mechanism of Pax 5 action is also largely unknown except for the observation that CTCF and Pax 5 may interact with each other in vivo. Further insight will be provided by identifying a critical subdomain of Pax 5 and the respective interacting proteins that mediate the role of Pax 5 in locus contraction. Moreover, the function of PAIR elements in $\mathrm{V}_{\mathrm{H}}-\mathrm{DJ}_{\mathrm{H}}$ recombination needs to be characterized by mutagenesis of these elements in the endogenous Igh locus. When compared with the Igh locus, even less is known about trans-acting factors or cis-regulatory elements that control locus contraction at other antigen receptor loci. Hence, elucidating the molecular mechanism of locus contraction will remain an interesting and challenging task for the future.

\section{ACKNOWLEDGMENTS}

This work was supported by Boehringer Ingelheim, the Vienna Science and Technology Fund (WWTF), an ERC advanced grant (291740-LymphoControl) from the Euro- 

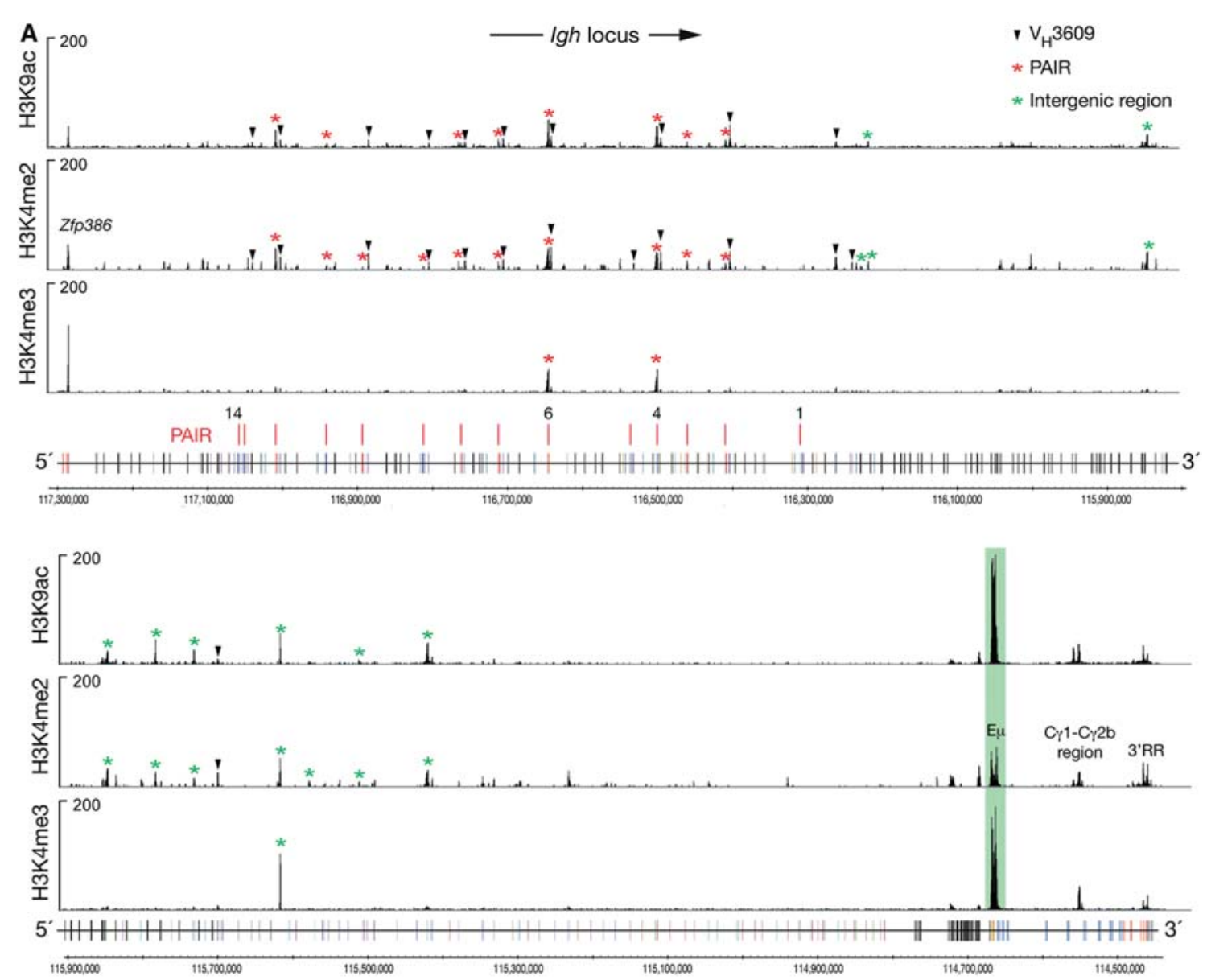

B

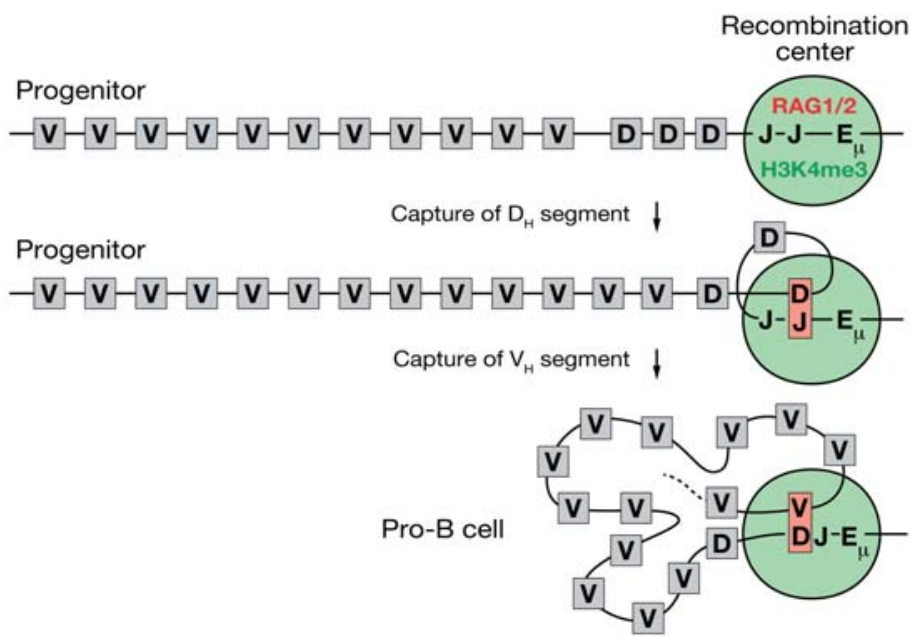

Figure 6. Active chromatin and the control of sequential rearrangements at the Igh locus. $(A)$ Distribution of active histone modifications at the Igh locus. The presence of $\mathrm{H} 3 \mathrm{~K} 4 \mathrm{me} 2$, H3K4me3, and H3K9ac was determined by ChIP analysis of Rag $2^{-/-}$pro-B cells combined with paired-end Illumina sequencing. The ChIP-seq data are displayed as peak densities that were calculated by extension of each read by $150 \mathrm{bp}$ and subsequent determination of the number of reads at each position (shown as reads per million [RPM] mapped sequence reads). The histone modification peaks detected at $\mathrm{V}_{\mathrm{H}} 3609$ genes, PAIR elements, and other intergenic regions in the $\mathrm{V}_{\mathrm{H}}$ gene region are indicated. The Zfp 386 gene located upstream of the Igh locus is indicated by red lines in the Igh annotation. $(B)$ The recombination center model. In lymphoid progenitors, the $\mathrm{E}_{\mu}$ enhancer activates the proximal $\mathrm{J}_{\mathrm{H}}$ gene region of the $I g h$ locus as a recombination center embedded in active chromatin. The RAG1/2 complex (red) is recruited in the recombination center through binding of the RAG2 PHD finger to the active histone modification H3K4me3 (green). The tethered RAG1/ 2 complex captures one of the $\mathrm{D}_{\mathrm{H}}$ gene segments, leading to $\mathrm{D}_{\mathrm{H}}-\mathrm{J}_{\mathrm{H}}$ recombination in progenitors followed by the subsequent capture of one of the many $\mathrm{V}_{\mathrm{H}}$ gene segments upon Igh locus contraction in pro-B cells. 
pean Community's Seventh Framework Program, the Austrian GEN-AU initiative (financed by the Bundesminsterium für Bildung und Wissenschaft), and an EMBO fellowship (to T.A.S.).

\section{REFERENCES}

Afshar R, Pierce S, Bolland DJ, Corcoran A, Oltz EM. 2006. Regulation of IgH gene assembly: Role of the intronic enhancer and $5^{\prime} \mathrm{D}_{\mathrm{Q} 52}$ region in targeting $\mathrm{D}_{\mathrm{H}} \mathrm{J}_{\mathrm{H}}$ recombination. $J$ Immunol 176: 2439-2447.

Bassing CH, Swat W, Alt FW. 2002. The mechanism and regulation of chromosomal V(D)J recombination. Cell 109: S45-S55.

Bolland DJ, Wood AL, Johnston CM, Bunting SF, Morgan G, Chakalova L, Fraser PJ, Corcoran AE. 2004. Antisense intergenic transcription in $\mathrm{V}(\mathrm{D}) \mathrm{J}$ recombination. Nat Immunol 5: 630-637.

Bossen C, Mansson R, Murre C. 2012. Chromatin topology and the regulation of antigen receptor assembly. Anпu Rev Immunol 30: 337-356.

Chakraborty T, Perlot T, Subrahmanyam R, Jani A, Goff PH, Zhang Y, Ivanova I, Alt FW, Sen R. 2009. A 220-nucleotide deletion of the intronic enhancer reveals an epigenetic hierarchy in immunoglobulin heavy chain locus activation. $J$ Exp Med 206: 1019-1027.

Choi NM, Loguercio S, Verma-Gaur J, Degner SC, Torkamani A, Su AI, Oltz EM, Artyomov M, Feeney AJ. 2013. Deep sequencing of the murine Igh repertoire reveals complex regulation of nonrandom $\mathrm{V}$ gene rearrangement frequencies. $J$ Immunol 191: 2393-2402.

Chowdhury D, Sen R. 2001. Stepwise activation of the immunoglobulin $\mu$ heavy chain gene locus. EMBO J 20: 63946403.

Degner SC, Verma-Gaur J, Wong TP, Bossen C, Iverson GM, Torkamani A, Vettermann C, Lin YC, Ju Z, Schulz D, et al. 2011. CCCTC-binding factor (CTCF) and cohesin influence the genomic architecture of the Igh locus and antisense transcription in pro-B cells. Proc Natl Acad Sci 108: $9566-$ 9571.

Deniaud E, Bickmore WA. 2009. Transcription and the nuclear periphery: Edge of darkness? Curr Opin Genet Dev 19: 187191.

Dixon JR, Selvaraj S, Yue F, Kim A, Li Y, Shen Y, Hu M, Liu JS, Ren B. 2012. Topological domains in mammalian genomes identified by analysis of chromatin interactions. Nature $\mathbf{4 8 5}$ : 376-380

Donohoe ME, Zhang LF, Xu N, Shi Y, Lee JT. 2007. Identification of a Ctcf cofactor, Yy1, for the X chromosome binary switch. Mol Cell 25: 43-56.

Ebert A, McManus S, Tagoh H, Medvedovic J, Salvagiotto G, Novatchkova M, Tamir I, Sommer A, Jaritz M, Busslinger M. 2011. The distal $\mathrm{V}_{\mathrm{H}}$ gene cluster of the Igh locus contains distinct regulatory elements with Pax 5 transcription factordependent activity in pro-B cells. Immunity 34: 175-187.

Fuxa M, Skok J, Souabni A, Salvagiotto G, Roldán E, Busslinger M. 2004. Pax 5 induces $V$-to- $D J$ rearrangements and locus contraction of the immunoglobulin heavy-chain gene. Genes Dev 18: 411-422.

Guo C, Gerasimova T, Hao H, Ivanova I, Chakraborty T, Selimyan R, Oltz EM, Sen R. 2011a. Two forms of loops generate the chromatin conformation of the immunoglobulin heavy-chain gene locus. Cell 147: 332-343.

Guo C, Yoon HS, Franklin A, Jain S, Ebert A, Cheng HL, Hansen E, Despo O, Bossen C, Vettermann C, et al. 2011b. CTCF-binding elements mediate control of V(D)J recombination. Nature 477: 424-430.

Hawwari A, Krangel MS. 2005. Regulation of TCR $\delta$ and $\alpha$ repertoires by local and long-distance control of variable gene segment chromatin structure. J Exp Med 202: $467-472$.
Hesslein DGT, Pflugh DL, Chowdhury D, Bothwell ALM, Sen R, Schatz DG. 2003. Pax5 is required for recombination of transcribed, acetylated, 5' IgH V gene segments. Genes Dev 17: $37-42$.

Hewitt SL, Farmer D, Marszalek K, Cadera E, Liang HE, Xu Y, Schlissel MS, Skok JA. 2008. Association between the Igk and Igh immunoglobulin loci mediated by the $3^{\prime} \operatorname{Ig} k$ enhancer induces 'decontraction' of the Igh locus in pre-B cells. Nat Immunol 9: 396-404.

Igarashi H, Gregory SC, Yokota T, Sakaguchi N, Kincade PW. 2002. Transcription from the RAG1 locus marks the earliest lymphocyte progenitors in bone marrow. Immunity 17: $117-$ 130.

Jankovic M, Casellas R, Yannoutsos N, Wardemann H, Nussenzweig MC. 2004. RAGs and regulation of autoantibodies. Annu Rev Immunol 22: 485-501.

Jhunjhunwala S, van Zelm MC, Peak MM, Cutchin S, Riblet R, van Dongen JJM, Grosveld FG, Knoch TA, Murre C. 2008. The 3D structure of the immunoglobulin heavy-chain locus: Implications for long-range genomic interactions. Cell 133: 265-279.

Ji Y, Resch W, Corbett E, Yamane A, Casellas R, Schatz DG. 2010. The in vivo pattern of binding of RAG1 and RAG2 to antigen receptor loci. Cell 141: 419-431.

Johnston CM, Wood AL, Bolland DJ, Corcoran AE. 2006. Complete sequence assembly and characterization of the C57BL/ 6 mouse Ig heavy chain $\mathrm{V}$ region. J Immunol 176: 42214234.

Kosak ST, Skok JA, Medina KL, Riblet R, Le Beau MM, Fisher AG, Singh H. 2002. Subnuclear compartmentalization of immunoglobulin loci during lymphocyte development. Science 296: $158-162$.

Kwon J, Morshead KB, Guyon JR, Kingston RE, Oettinger MA. 2000. Histone acetylation and hSWI/SNF remodeling act in concert to stimulate V(D)J cleavage of nucleosomal DNA. Mol Cell 6: 1037-1048.

Lin YC, Benner C, Mansson R, Heinz S, Miyazaki K, Miyazaki M, Chandra V, Bossen C, Glass CK, Murre C. 2012. Global changes in the nuclear positioning of genes and intra- and interdomain genomic interactions that orchestrate B cell fate. Nat Immunol 13: 1196-1204.

Liu Z, Widlak P, Zou Y, Xiao F, Oh M, Li S, Chang MY, Shay JW, Garrard WT. 2006. A recombination silencer that specifies heterochromatin positioning and Ikaros association in the immunoglobulin $\mathrm{\kappa}$ locus. Immunity 24: 405415.

Liu H, Schmidt-Supprian M, Shi Y, Hobeika E, Barteneva N, Jumaa H, Pelanda R, Reth M, Skok J, Rajewsky K, et al. 2007. Yin Yang 1 is a critical regulator of B-cell development. Genes Dev 21: 1179-1189.

Maes J, O'Neill LP, Cavelier P, Turner BM, Rougeon F, Goodhardt M. 2001. Chromatin remodeling at the Ig loci prior to V(D)J recombination. J Immunol 167: 866-874.

Malin S, McManus S, Cobaleda C, Novatchkova M, Delogu A, Bouillet P, Strasser A, Busslinger M. 2010. Role of STAT5 in controlling cell survival and immunoglobulin gene recombination during pro-B cell development. Nat Immunol 11: 171179.

Mathieu N, Hempel WM, Spicuglia S, Verthuy C, Ferrier P. 2000. Chromatin remodeling by the $T$ cell receptor (TCR)- $\beta$ gene enhancer during early T cell development: Implications for the control of TCR- $\beta$ locus recombination. $J$ Exp Med 192: $625-636$.

Mathieu N, Spicuglia S, Gorbatch S, Cabaud O, Fernex C, Verthuy C, Hempel WM, Hueber A-O, Ferrier P. 2003. Assessing the role of the $\mathrm{T}$ cell receptor $\beta$ gene enhancer in regulating coding joint formation during V(D)J recombination. J Biol Chem 278: 18101-18109.

Matthews AG, Kuo AJ, Ramón-Maiques S, Han S, Champagne KS, Ivanov D, Gallardo M, Carney D, Cheung P, Ciccone DN, et al. 2007. RAG2 PHD finger couples histone H3 lysine 4 trimethylation with V(D)J recombination. Nature 450: $1106-$ 1110. 
McMurry MT, Krangel MS. 2000. A role for histone acetylation in the developmental regulation of V(D)J recombination. Science 287: 495-498.

Medvedovic J, Ebert A, Tagoh H, Tamir IM, Schwickert TA, Novatchkova M, Sun Q, Huis in't Veld PJ, Guo C, Yoon HS, et al. 2013. Flexible long-range loops in the $\mathrm{V}_{\mathrm{H}}$ gene region of the Igh locus facilitate the generation of a diverse antibody repertoire. Immunity 39: 229-244.

Melchers F. 2005. The pre-B-cell receptor: Selector of fitting immunoglobulin heavy chains for the B-cell repertoire. Nat Rev Immunol 5: 578-584.

Merkenschlager M, Odom DT. 2013. CTCF and cohesin: Linking gene regulatory elements with their targets. Cell 152: 1285-1297.

Mostoslavsky R, Singh N, Kirillov A, Pelanda R, Cedar H, Chess A, Bergman Y. 1998. $\kappa$ chain monoallelic demethylation and the establishment of allelic exclusion. Genes Dev 12: $1801-1811$.

Nora EP, Lajoie BR, Schulz EG, Giorgetti L, Okamoto I, Servant N, Piolot T, van Berkum NL, Meisig J, Sedat J, et al. 2012. Spatial partitioning of the regulatory landscape of the X-inactivation centre. Nature 485: $381-385$.

Nutt SL, Urbánek P, Rolink A, Busslinger M. 1997. Essential functions of Pax5 (BSAP) in pro-B cell development: Difference between fetal and adult $\mathrm{B}$ lymphopoiesis and reduced $V$ to- $D J$ recombination at the IgH locus. Genes Dev 11: 476491.

Perlot T, Alt FW. 2008. Cis-regulatory elements and epigenetic changes control genomic rearrangements of the $\mathrm{IgH}$ locus. Adv Immunol 99: 1-32.

Perlot T, Alt FW, Bassing CH, Suh H, Pinaud E. 2005. Elucidation of IgH intronic enhancer functions via germ-line deletion. Proc Natl Acad Sci 102: 14362-14367.

Phillips JE, Corces VG. 2009. CTCF: Master weaver of the genome. Cell 137: 1194-1211.

Revilla-i-Domingo R, Bilic I, Vilagos B, Tagoh H, Ebert A, Tamir IM, Smeenk L, Trupke J, Sommer A, Jaritz M, et al. 2012. The B-cell identity factor Pax 5 regulates distinct transcriptional programmes in early and late B lymphopoiesis. EMBO J 31: 3130-3146.

Ribeiro de Almeida C, Stadhouders R, de Bruijn MJ, Bergen IM, Thongjuea S, Lenhard B, van Ijcken W, Grosveld F, Galjart N,
Soler E, et al. 2011. The DNA-binding protein CTCF limits proximal Vк recombination and restricts $\kappa$ enhancer interactions to the immunoglobulin $\kappa$ light chain locus. Immunity 35: $501-513$.

Roldán E, Fuxa M, Chong W, Martinez D, Novatchkova M, Busslinger M, Skok JA. 2005. Locus 'decontraction' and centromeric recruitment contribute to allelic exclusion of the immunoglobulin heavy-chain gene. Nat Immunol 6: $31-41$.

Sayegh C, Jhunjhunwala S, Riblet R, Murre C. 2005. Visualization of looping involving the immunoglobulin heavy-chain locus in developing B cells. Genes Dev 19: 322-327.

Seitan VC, Hao B, Tachibana-Konwalski K, Lavagnolli T, Mira-Bontenbal H, Brown KE, Teng G, Carroll T, Terry A, Horan K, et al. 2011. A role for cohesin in T-cell-receptor rearrangement and thymocyte differentiation. Nature 476: 467-471.

Shih H-Y, Verma-Gaur J, Torkamani A, Feeney AJ, Galjart N, Krangel MS. 2012. Tcra gene recombination is supported by a Tcra enhancer- and CTCF-dependent chromatin hub. Proc Natl Acad Sci 109: E3493-E3502.

Skok JA, Gisler R, Novatchkova M, Farmer D, de Laat W, Busslinger M. 2007. Reversible contraction by looping of the Tcrb and Tcra loci in rearranging thymocytes. Nat Immunol 8: $378-387$.

Tripathi R, Jackson A, Krangel MS. 2002. A change in the structure of V $\beta$ chromatin associated with TCR $\beta$ allelic exclusion. J Immunol 168: 2316-2324.

van de Werken HJ, de Vree PJ, Splinter E, Holwerda SJ, Klous P, de Wit E, de Laat W. 2012. 4C technology: Protocols and data analysis. Methods Enzymol 513: 89-112.

Verma-Gaur J, Torkamani A, Schaffer L, Head SR, Schork NJ, Feeney AJ. 2012. Noncoding transcription within the Igh distal $\mathrm{V}_{\mathrm{H}}$ region at PAIR elements affects the 3D structure of the Igh locus in pro-B cells. Proc Natl Acad Sci 109: 17004-17009.

Xiang Y, Zhou X, Hewitt SL, Skok JA, Garrard WT. 2011. A multifunctional element in the mouse $I g \kappa$ locus that specifies repertoire and Ig loci subnuclear location. J Immunol 186: 5356-5366.

Yancopoulos GD, Alt FW. 1985. Developmentally controlled and tissue-specific expression of unrearranged $\mathrm{V}_{\mathrm{H}}$ gene segments. Cell 40: $271-281$. 


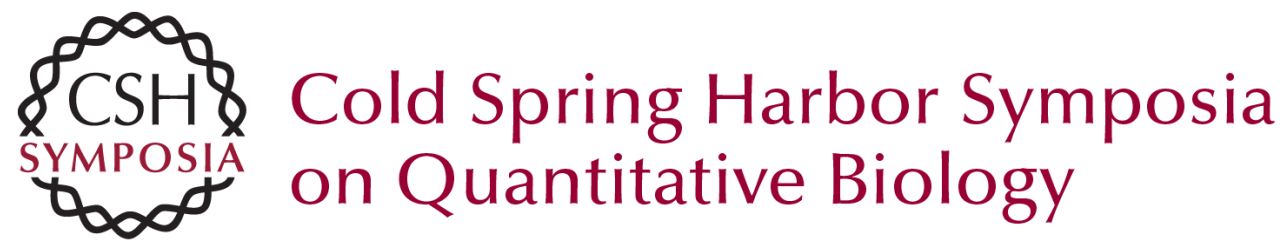

\section{Control of Antigen Receptor Diversity through Spatial Regulation of V(D)J Recombination}

Anja Ebert, Jasna Medvedovic, Hiromi Tagoh, et al.

Cold Spring Harb Symp Quant Biol 2013 78: 11-21 originally published online February 28, 2014 Access the most recent version at doi:10.1101/sqb.2013.78.019943

References This article cites 55 articles, 24 of which can be accessed free at: http://symposium.cshlp.org/content/78/11.full.html\#ref-list-1

License

Email Alerting Receive free email alerts when new articles cite this article - sign up in Service the box at the top right corner of the article or click here. 